\title{
The Phenomenon of Rewriting Scripture in Late Second Temple Judaism: Some Methodological Reflections on the So-Called "Rewritten Bible" Category
}

\author{
MARCIN MAJEWSKI \\ Pontifical University of John Paul II in Krakow \\ marcin.majewski@upjp2.edu.pl, ORCID: 0000-0002-4362-4812
}

\begin{abstract}
The term "Rewritten Bible" was introduced by Géza Vermes in 1961 to describe works from late Second Temple period that "retell" or "rewrite" Scriptures with characteristic changes. Since then, much has been written about this category of texts. Today some researchers are tired of discussing this concept, suggesting even a move away from the notion. Others, on the contrary, apply it to an increasing number of texts, including even works lying outside the specific context of late Second Temple Jewish literature. This article discusses the phenomenon of the "Rewritten Bible" (RewB) and takes up a polemic with certain approaches to the category, concerning terminology, scope, and character, as well as indication of the purposes of rewriting activity. The article shows that the category remains useful and important, within certain methodological clarifications.
\end{abstract}

Keywords: Rewritten Bible, Rewritten Scripture, Book of Jubilees, Antiquities of the Jews, Genesis Apocryphon, 4QReworked Pentateuch

Few terms have elicited as many vivid reactions among exegetes as the term "Rewritten Bible," proposed in 1961 by Géza Vermes. ${ }^{1}$ The impetus for the lively debate was primarily the discovery of the Dead Sea Scrolls, including previously unknown writings that Vermes, and others after him, classified as "Rewritten Bible" (henceforth RewB). It is an ancient practice of interpreting the sacred texts of Judaism, which involved not so much commenting or discussing them, as telling or rewriting anew, often with significant additions, omissions, and other kinds of changes. The new phase of the debate that continues until today began with the complete publication of the Qumran texts - and especially the texts of Cave Four - in the beginning of the nineties.

The article was prepared as part of research project No. UMO-2013/09/D/HS1/00447 financed by the National Science Center.

1 Vermes, Scripture and Tradition, 95. 
The Qumran texts clearly showed that ancient scribes modified and supplemented some of the biblical stories. What made them feel that they could do this and that they should change sacred texts in a certain way? What was their attitude towards the source texts they interpreted so freely? Contemporary exegetes were surprised by how easily the biblical text was revised at the time when the canon of the Bible seems to have been roughly established. Certainly, the authority of the Pentateuch was specified - and most of the works of the RewB focus on the Torah (Pentateuch). ${ }^{2}$

How to name this phenomenon? "Rewritten Bible"? "Retold Bible"? "The Bible Reinterpreted"? "Para-Bible"? Or maybe the word "Bible" should be replaced by something else? What is its scale and scope? How to characterize the phenomenon itself? Is it a literary genre or a textual strategy present in various genres? An exegetical technique or a loose form of literary activity? Does it concern only texts written in Hebrew and can it be a solution to the Synoptic Problem?

Today, the RewB category is understood and implemented differently by individual researchers. Some of them are tired of discussing this concept, suggesting even abandoning it. ${ }^{3}$ Others, on the contrary, apply it to an increasing number of texts, including even works lying outside the specific context of late Second Temple Jewish literature. In this article, I want to look at the phenomenon of "rewriting" authoritative texts and engage in a polemic with some approaches to the RewB phenomenon in the literature on the subject, incl. the terminology, the scope of the phenomenon in question, and the indication of the purpose(s) of the works of RewB. I will try to show old and new anachronisms accompanying the debate and convince that the category remains useful and important, within certain methodological clarifications.

\section{The Phenomenon of Rewriting the Scripture}

Some of the early interpretations of the Bible - or rather the interpretations of the sacred texts of Judaism, as the term "Bible" seems an anachronism at this stage achieved their purpose by rewriting the biblical stories with the addition, omission and alteration of certain important threads, or retelling them in a modified form. In other words, some early Jewish writings interpret the books that now make up the Hebrew Bible by re-narrating them - rather than commenting on them in the verse-byverse form known from rabbinical sources and modern critical commentaries on the Scripture. We observe this phenomenon not only in the writings preserved at

\footnotetext{
2 The ambiguous term "Torah" will be used here as a synonym for the Pentateuch - the first five books of the Bible.

3 See the questions posed by researchers in: Zsengellér (ed.), Rewritten Bible after Fifty Years.
} 
Qumran, where the classic examples are the Book of Jubilees ${ }^{4}$ and the Genesis Apocryphon, ${ }^{5}$ but also in Josephus, esp. in his Antiquitates Judaicae, in the extra-biblical texts of early Judaism, and, interestingly, in the Bible itself. The best example here are the Books of Chronicles - a creative "rewriting" of the older traditions contained in the Books of Samuel and Kings (with significant omissions and modifications). In addition, there are also the traditions worked out in the Book of Deuteronomy, derived from the books of Exodus and Numbers (e.g., the Decalogue). We also have examples of reusing or updating older materials in the younger prophetic books. ${ }^{6}$

In some texts of the RewB, fragments of the narrative are literally copied, in others paraphrased in the author's own words, and elsewhere retold anew and with changes. The author may omit some episodes, drastically shorten others, add supplements that will create an original explanation of the transcribed text, or finally incorporate completely new traditions and motifs from other sources. Géza Vermes has identified RewB as "a narrative that follows scripture but includes a substantial amount of supplements and interpretative developments." In the beginning, he did not propose any analytical definition for his term. Later, he returned to the topic, trying to specify it. He wrote that the RewB is characterized by "a close attachment, in narrative and themes, to some book contained in the present Jewish canon of Scripture, and some type of reworking, whether through rearrangement, conflation, or supplementation

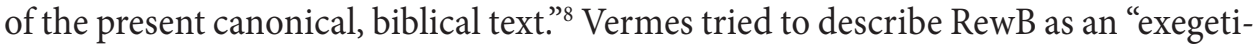
cal process" analogous to the creation of the midrash. In his opinion, the scribe created "haggadic development into the biblical narrative [...] in order to anticipate questions, and to solve problems in advance." He saw the midrashic nature of RewB in frequent reading and interpreting the Scripture with the intention of explaining and supplementing its stories and resolving textual, contextual and doctrinal difficulties. Such creative reading leads to a RewB - a fuller, smoother, and doctrinally more

4 Book of Jubilees, also called the Little Genesis, is a pseudepigraphal work from the 2nd century BCE that presents the narrative of Genesis and the beginning of Exodus by retelling biblical stories in these books from a different perspective. It is notable, inter alia, for its chronological schema, by which events described in Gen and Exod are dated by jubilees of 49 years, each of which is composed of seven cycles of seven years.

5 Genesis Apocryphon (1Q20), also called the Tales of the Patriarchs, is one of the seven original scrolls from the first Qumran cave. The preserved fragment contains the stories about Lamech, Noah and Abraham, parallel to the text of the Book of Genesis. In many places, it is very close to the biblical text, in some it has exegetical inserts and explanations similar to the rabbinic midrash, and in others it contains completely new material, not known from the biblical tradition.

6 Whereas in the earlier period one may find rewritings of individual laws, prophecies, or narrative passages, the further one moves into the latter part of the Second Temple period the more extensive becomes the scale of rewriting, since entire works such as Chronicles, Book of Jubilees, Antiquitates Judaicae, and the Temple Scroll, rewrote complete literary works; see Segal, "Between Bible," 28.

7 Vermes, Scripture and Tradition, 95.

8 Vermes, "Bible Interpretation," 186-188.

9 Vermes, Scripture and Tradition, 95. 
advanced form of narrative. ${ }^{10}$ In this sense, Géza Vermes initially understood the term as a "textual strategy," and therefore a kind of exegesis. Later, he used it somewhat vaguely as a defined "genre." II will deal with this conclusions below.

It is important to distinguish here the phenomenon of rewriting the Bible anew from pseudepigrapha and apocrypha, which may be related to a person or event in the present canonical text, but in fact mostly contain new material, and use the biblical text only to a limited extent. ${ }^{12}$ RewB is characterized by a parallelism to and close relationship with the scriptural base text. It must closely follow and work through it. ${ }^{13}$ In the collection of RewB scholars usually mention the Book of Jubilees, the Genesis Apocryphon, Antiquitates Judaicae, not infrequently also the biblical Books of Chronicles, the $4 \mathrm{QReworked} \mathrm{Pentateuch} \mathrm{(4QRP)}{ }^{14}$ or, less frequently, the Testaments of the Twelve Patriarchs. ${ }^{15}$ The fact that all these works (apart from that of Josephus Flavius) are present in the Qumran library shows that this way of reading the sacred texts was widespread and appreciated in the Essene community. ${ }^{16}$ However, the Book of Jubilees or the Books of Chronicles are well attested also outside the Qumran community, which shows that RewB was more widely known in Second Temple Judaism.

The textual base of these compositions differs from case to case. Some contain non-Masoretic readings, especially from the LXX and the Samaritan Pentateuch group, some are based on Qumran texts, while the textual base of others is not known from anyone text with which we are familiar. For example, in his rewriting of Samuel, the Chronicler often did not use MT or the Hebrew Vorlage of the LXX, but a text like $4 \mathrm{QSam}$, one of the Samuel manuscripts from Qumran. The Books of Chronicles are closer to $4 \mathrm{QSam}{ }^{\mathrm{a}}$ than to MT. ${ }^{17}$

10 Vermes, "Biblical Midrash," 308.

11 Vermes, "Bible Interpretation," 185-188.

12 The list of such apocryphal works is long, it is enough here to mention the Apocryphon of Jacob, Testament of Judah, Testament of Levi, Aramaic Levi Document, Visions of Amram, Words of Moses, Vision of Samuel, Pseudo-Ezekiel or Pseudo-Daniel.

13 Betsy Halpern-Amaru points this out in his book: Rewriting the Bible, 4.

14 4QReworked Pentateuch is a group of texts found in the fourth Qumran cave (4Q158, 4Q364-367), officially published in the mid-1990s. Their content includes partially unchanged legal fragments of the Pentateuch, and partially modified and supplemented ones. The main debate in recent years on the 4QReworked Pentateuch concerns the question of whether the texts of 4QRP should be treated as a copy of the Torah or an extended, independent work from the Rewritten Bible category. See Zahn, "The Problem of Characterizing," 315-339; Zahn, Rethinking Rewritten Scripture.

15 Testaments of the Twelve Patriarchs is an apocryphal book probably written around 150 B.C. in Greek among Jews living in the Diaspora. The book consists of the testaments of the 12 sons of the patriarch Jacob. The content is structured and includes a biography, admonitions and encouragement, and the fate of each generation. The stories of Reuben, Simeon, Levi, Judah, Issachar, Zebulun, Naphtali, Gad, Asher, Joseph, and Benjamin are described. Interestingly, there are numerous similarities with the texts of the New Testament, which are understood as Christian interpolations, or possibly as pre-Christian material used by both the author of the apocrypha and the Christian authors.

16 I assume the identification of the community of Qumran with the Essenes movement.

17 Talshir, "The Relationship," 273-298. 


\section{Clarification of Terminology}

At the very outset of terminological considerations, an important distinction must be made, distinction that is sometimes completely ignored. "Rewritten Bible" is a modern analytical term which has been defined in relation to ancient (Jewish) writings related to the biblical texts. While the terms "pesher," "midrash" and "targum," for example, are used in ancient sources, RewB has never been used.

\begin{tabular}{|l|l|l|}
\hline & \multicolumn{1}{|c|}{ Terms used in ancient texts } & \multicolumn{1}{c|}{ Terms used in modern analyses } \\
\hline Ancient terms & pesher, midrash, targum & pesher, midrash, targum \\
\hline Modern meta-level terms & - _ . . . - . & Rewritten Bible \\
\hline
\end{tabular}

RewB is analytical scholarly term the aim of which is to grasp some literary phenomena attested in ancient texts. This means that RewB cannot be discussed in a same way as pesher, midrash and targum which are terms appearing in ancient texts. In this sense the term RewB is anachronistic, i.e., it is modern scholarly term which is dependent on the way how scholars use it. Some researchers postulate to separate the works of RewB from peshers, midrashes and targums - to make this category more specific. Thus, they equate the different levels on which these terms function. And yet it is possible that midrash stories or targums contain literary activity specific to the RewB.

The term RewB is anachronistic for one more reason. When we consider the fact that at least until the beginning of the second century C.E. there was no set canon of the Hebrew Bible - so there was no "Bible" - the term "Rewritten Bible" turns out to be an anachronism in this case. Recently researchers have rightly grown suspicious of the word "Bible" it contained. James VanderKam had made it clear that there was neither a closed, nor even a fixed tripartite canon prior to the late first century and early second century $\mathrm{CE}$ at the earliest. ${ }^{18} \mathrm{He}$ was one of the first to propose the term "Rewritten Scripture" (henceforth RewS) instead of "Rewritten Bible." ${ }^{19}$ His argument was adopted by others. Petersen, for example, replaces "Bible" with "Scripture" and defines Scripture as any writing or book that is attributed a particular authoritative status, especially in the context of writings of a sacred or religious nature. ${ }^{20}$

\footnotetext{
18 VanderKam, "The Wording of Biblical Citations," 52-54.

19 VanderKam, "The Wording of Biblical Citations," 42f. See also Campbell, "«Rewritten Bible» and «Parabiblical Texts»", 49.

20 Petersen, "Rewritten Bible," 287. Jonathan Campbell also writes about the anachronistic and too narrow character of the term Rewritten Bible. See Campbell, "«Rewritten Bible» and «Parabiblical Texts»", 48-50; Campbell, "Rewritten Bible: A Terminological Reassessment," 49-81.
} 
Indeed "Rewritten Scripture" or "Rewritten sacred Scriptures" seems to be a better solution in a situation where the canon of the Bible is not yet clearly defined. But here comes a problem analogous to the consternation around the notion of RewB. Researchers rightly prefer the term "Rewritten Scripture," but at the same time they fall into Vermes' confusion by failing to define the term Scripture (Petersen is a rare exception here). When we discuss the textual evidences of the pre-canonical, late Second Temple era, terms such as "Scripture" or "scriptural," now used by many, also may create some difficulties. After all, in the basic sense in English it is synonymous with the "Bible." Is "scriptural" just "authoritative" or maybe something more, "canonical" or "biblical"? In my opinion, the term "Scripture" or "Scriptures" - used in the concept of RewS - unlike Bible, does not refer to a canonically defined collection of writings that has been definitively and formally closed. It indicates a character (holy writings) rather than a specific corpus. It results in the broadening of the scope of meaning that Géza Vermes initially intended. RewS encompasses various authoritative writings from the Second Temple period, including biblical ones (where we also meet the phenomenon of rewriting). Such an approach better reflects the reality of the creation of rewritten works, at the same time allowing to take into account the multitude of different forms of texts and the dynamism of literary processes. The term RewS emphasizes the way authoritative writings are used as matrices for the creation of authoritatively derivative texts, which by virtue of being rewritings contribute to the authoritative elevation of their antecedents, ${ }^{21}$ whilst on the other hand the rewritings sun themselves in the authoritative light of their predecessors. ${ }^{22}$

Géza Vermes, in his last paper on the subject - unfortunately he died before its publication - defended the term "Bible" by suggesting that replacing it with "Scripture" is just a terminological trick. ${ }^{23}$ This is true only if we do not properly define the term "Scripture(s)," emphasising that here it is not synonym of the "Bible." At the time the analyzed texts were written, there were no strict boundaries between biblical and non-biblical texts, between canonical and parabiblical texts. On the contrary, the situation was pluralistic both textually and canonically. ${ }^{24}$ If no canon existed prior to, say, the late 1st century C.E., sticking to the term "Bible" or "biblical" appears misleading. The term "Rewritten Bible" - that is, derivative, secondary, non-canonical work - does not fit, for example, the Books of Chronicles, which are not so much RewB as the Bible itself. Similarly, the Book of Jubilees could be treated as the Qumran Bible rather than rewritten Bible. ${ }^{25}$ Rewriting of Scripture may

\footnotetext{
21 Petersen, "Rewritten Bible," 287.

22 Malan, "Rewritten Bible/Scripture," 2.

23 Vermes, "The Genesis of the Concept," 3-9: "Frankly, replacing «Bible» by «Scripture» strikes me as a mere quibble" (ibidem, 8).

24 See Najman, "The Vitality of Scripture," 497-518.

25 In certain cases it is difficult to decide whether some texts are scriptural or not, e.g. Jubilees, the Book of Enoch, 4QReworked Pentateuch.
} 
become authoritative as is well known from cases such as Deuteronomy or perhaps the 4 QReworked Pentateuch as well. ${ }^{26}$ One group's rewritten Bible could very well be another's biblical text. This examples shows at least two things: 1) that the relationship between the Scripture and the rewritten Scripture is complex, and the transition between the two is inherently fluid; 2) that the rewritten texts of Scripture could acquire the same authority as their written predecessors, they could become authoritative Scripture. The reverse process is also possible: some works were initially given high status, but then they lost that status.

Some scholars prefer the term "Parabiblical," but for the same reasons, it is an anachronism. It still includes the term "Bible" in this context, and it rejects in advance the possible canonical and authoritative status of the RewB itself (parabiblical - meaning non-biblical). Daniel Falk admits in his monograph The Parabiblical Texts that the so-called parabiblical texts are "lying between 'biblical' text and exegesis, but in certain cases it is hard to identify that what a 'biblical' text is." ${ }^{27}$ Generally, in the discussion on the RewB phenomenon, anachronistic categories are easily reached.

\section{The Temple Scroll and Other Legal Texts}

The scope of texts that are examined under the so-called RewB category varies, depending on the attitude of the researchers. In the beginning, Géza Vermes and his successors limited the number of texts to very specific writings of Second Temple Judaism, always narratives (like the Book of Jubilees and the Genesis Apocryphon). ${ }^{28}$ On this basis, they draw conclusions as to the whole phenomenon. But what about legal texts like the Temple Scroll (11QTemple Scrolla)? Philip Alexander in the 80s followed Vermes' original understanding of the notion and argued that rewritten biblical texts are always narratives, following the Scriptures in chronological order and

26 VanderKam, "Questions of Canon," 96-100; Lange, "The Status of the Biblical Texts," 27; Tov, "3 Kingdoms," 365-366; Tov, "The Many Forms," 11-28. These researchers indicate that 4QRP was the authoritative text in Qumran as representing expanded scriptural text. Sidnie Crawford is somewhat more cautious acknowledging that at least some of the 4QRP mss "were meant by the scribes that prepared them to be read as regular pentateuchal texts," but noting also that we have little clear evidence that they were considered authoritative by any particular group (Crawford, Rewritten Scripture, 56-57). Daniel Falk (The Parabiblical Texts, 111) shares a similar opinion as Crawford.

27 Falk, The Parabiblical Texts, 1.

28 See, for example, Alexander, "Retelling the Old Testament," 99-121 (he only includes the Genesis Apocryphon, the Book of Jubilees, Josephus' Antiquities, and the Liber Antiquitatum Biblicarum). More recent, see Zahn, "Rewritten Scripture," 323-336 (where only four Qumran texts are analyzed: the Book of Jubilees, Genesis Apocryphon, Temple Scroll, and 4QReworked Pentateuch); Falk, The Parabiblical Texts (where only three works are analyzed: Genesis Apocryphon, Reworked Pentateuch, and 4Q Commentary on Genesis A-D). 
covering much of the content of Scripture. ${ }^{29}$ Alexander's definition excluded legal and ritual texts from the category mainly for reasons of difficulties in clearly grasping the phenomenon of rewriting or working through a specific text. ${ }^{30}$

Daniel Harrington, as far as I know, was the first to include the Temple Scroll in the category. ${ }^{31}$ Since then an increasing number of scholars began to broaden the notion to include the Temple Scroll, often, however, without any particular argumentation. Does the RewB include also halakhic, i.e., legal texts? It seems that the answer should be positive. An analysis of Josephus' Antiquities shows that author works not only with biblical narratives and stories, but also with significant parts of legislative texts, especially the legal and ritual material of the Pentateuch. This indicates that the creative work of retelling the sacred traditions was not limited to narrative texts, but also included law. We observe this phenomenon in the analysis of the Temple Scroll. Its author uses the same techniques found in narrative texts to demonstrate that the extrapentateuchal legislation that he embraces was also given by God to Moses on Mount Sinai. As Emanuel Tov has shown, some parts of the Temple Scroll are even closer to the biblical text than the 4 QReworked Pentateuch, while others contain explicit reworkings of the laws of the Torah. Some parts of the Temple Scroll and large parts of the 4QRP are copies of the laws of the Pentateuch, while others are more or less reworked by their authors/redactors, thus meeting the same definition as the narrative texts of RewB.

Moshe Bernstein argued some time ago for inclusion of the Temple Scroll as the "sole" legal exemplar of RewB. ${ }^{32}$ But what about other legal texts? In the Book of Jubilees - the classic example of RewB - we find also laws and legal texts, esp. in the final two chapters of the book. After narrating the story of the Exodus from Egypt, Jubilees gathers laws of Passover from a variety of biblical locations, adds some biblically unattested Passover rules, and presents them as a coherent unit (49:1-23), with the heading, "Remember the commandment which the Lord commanded you concerning the Passover" (49:1). This is followed by a similar grouping and expansion of Sabbath laws (50:1-13). This is also rewriting of Scriptures. And what about smaller legal texts? Qumran legal texts, such as 1Q22, 2Q21, 4Q368, 4Q408 or 4Q577, ${ }^{33}$ are very rarely taken into account, while there are numerous biblical rewritings, quotations and paraphrases in them. Such legal texts focus on working through the law of

29 Alexander, "Retelling the Old Testament," 99-121.

30 Alexander, "Retelling the Old Testament," 103.

31 See Harrington, “The Bible Rewritten," 239-247. Steven Fraade is wrong saying that in Harrington's publication there is "nothing to suggest that there might be legal texts to be considered in this regard" (Fraade, "The Temple Scroll," 136).

32 Bernstein, "Rewritten Bible," 193-195. See, more recently, Fraade, "The Temple Scroll," 136-154. Fraade examines the category of "Rewritten Bible/Scripture," pushing for the inclusion of legal material within it and positing that the Temple Scroll does fit this mold.

33 The above-mentioned texts are analyzed, in the RewB category, in the book: Feldman - Goldman, Scripture and Interpretation. 
the Pentateuch, mainly that found in Genesis, Exodus, and Leviticus. Therefore, in the discussion on the RewB category, it seems that one should not reject a priori texts that rewrite biblical law.

We are still before the step of possible inclusion of other than Temple Scroll legal texts to the category. Today we understand better that the sample of few narrative texts is too small to judge the RewB phenomenon and that it is not limited to just a few great Qumran works. It is traditionally assumed that the phenomenon of socalled RewB was present in late Second Temple Judaism (2th century BC to 1st century $\mathrm{AD}$ ). But we should also remember that textual activity found in RewB phenomenon is also evident within a wider range of Second Temple literature than is normally acknowledged.

\section{Translations, Gospels and Works from the Christian Era}

The analysis of the RewS can go in two different directions. Some researches narrow the category down to a few specific texts from Second Temple times. They operate according to the principle that while every work of the RewS is a biblical interpretation, not every biblical interpretation is automatically a RewS. Others, in turn, try to include in the collection more and more new works that are somehow related to the Scripture. They believe that any form of paraphrase or interpretation of biblical content already falls under this category, and since the RewS does not have to repeat the present canonical text, it is enough that it alludes to it and reinterprets it. This illustrates well how the definition of RewS, and what "Scripture" means here, is related to modern scholarly evaluations how the term should be used.

What about ancient translations? Could any translation that is not literal fall into the so-called RewB category? Those who draw the limit of the phenomenon most broadly, think so. ${ }^{34}$ On a scale from manuscript copies containing minor revisions, through translations which follow the base text more or less closely and through retellings of scriptural narratives to compositions based only loosely on the Hebrew Bible - translations are inherently close to the source text, but the language changes. In the works of RewS, the language most often does not change (this is not the case), but the final text vary in relation to the source text. Some researchers exclude translations from RewS category assuming that it describes only works written in the same language as the original. Although the exclusion of translations seems justified - this is yet another kind of literary activity - the linguistic criterion is artificial. It would exclude, for example, Genesis Apocryphon written in Aramaic or Flavius who writes

34 See more in Segal, "Between Bible," 10-29; Crawford, Rewritten Scripture, 48-50. Vermes, for example, used the Palestinian Targum as an example of RewB. 
in Greek. Josephus' Antiquities of the Jews are not a translation of Hebrew Scriptures - as he stipulates in the prologue - but a reworking of biblical traditions created in the form of rewritten Scripture. ${ }^{35}$

Some want to expand the scope of the RewB category with the synoptic Gospels. They actually see in the RewB discussion a solution for the so-called Synoptic Problem. ${ }^{36}$ Irrespective of the question of Q, it is incontestable that the Gospel of Matthew rewrites Mark, its predecessor, by exhibiting a number of features such as adjustments, omissions, rearrangements and supplementations which at the level of content are understood to be prime characteristics of RewS. ${ }^{37}$ Recently, several works have been written that view the process of creating synoptic Gospels analogously to the "rewriting" of the Scripture. In the collective work Luke's Literary Creativity (2016), ${ }^{38}$ the authors propose a reading of the Gospel according to Luke as rewriting the life of Jesus contained in the Gospel of Matthew ${ }^{39}$ and working through biblical motives from the Hebrew Bible, especially relating to Elijah and Moses. ${ }^{40}$ This approach to the discussed notion has many advantages, but there are also few problems with it. A most important one is the relatively short time between the writing of

35 In eleven chapters of his opus magnum Flavius recounts a story known from the books of the Bible in a detailed way. He does not so much analyzes individual texts, does not give a philological, literary or theological interpretation of them, as he re-narrates them, remodeling the Semitic world of Hebrew culture into the Greek world of Platonic ideas. Material that may sound offensive or incomprehensible he omits or only mentions, and adds elements that answer actual or supposed questions and difficulties of a non-Semitic reader. Commenting on his own methodology, Flavius Josephus writes in the introduction to Antiquitates Judaicae that the content of the work will be "translated ( $\mu \varepsilon \theta \varepsilon \rho \mu \varepsilon v \varepsilon v$ w) from the Hebrew scriptures" (Ant. 1.5). He states that the work should be treated as a translation, nothing more. Else-

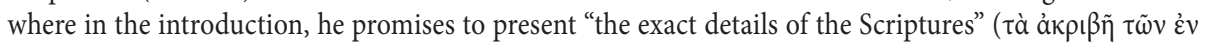

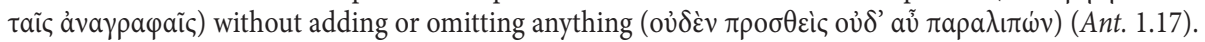
However, his assurances that he would not add anything or omit anything do not correspond to his actual literary practice. In fact, he approaches base texts in the form of the biblical books very loosely. His text is so far from being a translation that it is in fact a completely new and different text, although the dependence on the form and content of Scripture is very clear. The work of Flavius can be characterized as a very creative process of using the Scriptures, in which Flavius translates, adapts or synchronizes the versions found in the Vorlagen. This causes a number of changes to the plot of the narrative, the theological motives associated with it, as well as the roles of the characters. This fully qualifies this work as RewS. For more see Friis, Translations.

It seems that Jonathan Campbell ("«Rewritten Bible» and «Parabiblical Texts»," 50) was the first scholar to suggest the inclusion of New Testament texts in the RewB group. In his 2005 essay, he mentions texts such as Acts 7 and Hebrews 11 in the context of "Rewritten Bible."

37 Petersen, "Textual Fidelity," 36.

38 Müller - Tang Nielsen, Luke's Literary.

39 Especially in the first part, where we have articles such as: "Luke Uses/Rewrites Matthew" (Vadim Wittkowski); "Re-walking the 'Way of the Lord': Luke's use of Mark and his Reaction to Matthew" (Mark Goodacre); "Luke Rewriting and Rewritten (Francis Watson) or Acts as Biblical Rewriting of the Gospels and Paul's Letters" (Mogens Müller).

40 Here especially part two and articles such as: "Rewritten Prophecy in Luke-Acts" (Lukas Bormann); "The Lord Elijah in the Temple as in Malachi 3.1: 'Overkilling' Elijah Tradition in Luke 2" (Lotta Valve) or "Luke's Use of the Old Testament in the Sending of the Seventy Two" (Joseph Michael Lear). 
individual Gospels - time too short to speak of rewriting "sacred," "scriptural" texts. In the phenomenon of rewriting, called by Géza Vermes "rewritten Bible," an irremovable element is authoritative, sacred status of retold works as Scriptures.

Anyway, an attempt is made in recent years to analyze more and more new texts and groups of texts using the RewS category. Some include into the group the above-mentioned Testaments of the Twelve Patriarchs or the Testament of Moses (also called the Assumption of Moses), the apocrypha built on the story from Deut 31-34, but mostly containing of new content, absent in the Bible. ${ }^{41}$ Others include gnostic texts such as the Gospel of Judas and the Gospel of the Saviour. Still others use the notion to explore works of Epiphanius of Salamis, the bishop of Salamis, Cyprus at the end of the 4th century ${ }^{42}$ or the composition known as the Cave of Treasures, transmitted under the name of Ephrem the Syrian (fourth century), but most likely composed not earlier than the first decades of the sixth century ${ }^{43}$ or even Palaea Historica ("Old Testament History"), an anonymous work composed sometime in the late ninth to early tenth centuries, that is probably most noteworthy for its copious assortment of parabiblical legends about biblical personalities. ${ }^{44}$

We are now in a phase where, on the one hand, a natural skepticism about the idea of RewB has arisen, and on the other, rewritten Bible is applied to an increasing number of texts, including, as one can see, texts of the nascent and developing Christ-movement. This inclusion in the category of still new writings from different periods and social worlds shows that the category is attractive and maybe useful as a research tool, but scholars are not keeping up with its development. What is needed is not so much to reject the concept, but to refine it and clarify each time it is used.

In my opinion, the above-mentioned attempts to constantly broaden the category break its internal logic and make this concept so capacious that it ceases to be operative. First, the RewS phenomenon is about rewriting, reworking the base text, perhaps with the intention of replacing it (see below), and not about using it on the basis of intertextuality. Second, in the conceptual framework of the initiators, the RevB applies to Second Temple period Jewish texts, and not to any writings based on the authoritative status of their predecessors (although there are many analogies in the literature). Third and most importantly, the phenomenon of creative rewriting of the Scriptures is possible only when authoritative texts have not yet acquired the status of canonical and unambiguously closed collection of Holy Scriptures. When the biblical text obtained the status of canonical and unchangeable, then

\footnotetext{
41 See, for example, Parchem, "Testament Mojżesza," 79-103.

42 Reed, "Retelling Biblical Retellings," 308-309.

43 "This work belongs to the category of «Rewritten Bible»: it offers a retelling of sacred history from the first day of creation until Pentecost, based on the Hebrew Bible and the New Testament, but also drawing on patristic and apocryphal sources" (Minov, "Satan's Refusal," 244).

44 Van Loon, "The Meeting of Abraham," 1376. David Flusser ("Palaea Historica," 78-79) also saw Palaea Historica in RewB terminology.
} 
the exegesis and actualization had to go beyond the biblical text itself and abandon the practice of "rewriting" the Scriptures. In response to the question why this form of biblical interpretation seems to be dying out after the first century C.E., it can be argued that it was precisely the process of establishing and stabilizing the canon of the Bible. This left much less room for new arrangements and new approaches to sacred traditions. This observation excludes any works that are created in the second century C.E. and later, because it is then that the phenomenon of RewB captured by Géza Vermes ends - and the process of multi-level interpretation of the canonically defined Bible begins and develops. Among others, the structured format of "verse plus commentary" become the dominant form of interpretation of both rabbinic Judaism and early Christianity.

Therefore, in order for the term RewB not to be a bottomless pit, but to be operational, several categories of texts should be excluded from its scope (bearing in mind that the clear distinction between them is neither simple nor obvious): 1) copies and revisions of biblical texts; 2) biblical translations; 3 ) the apocrypha and other works that possess most of the new material not found in the Bible; 4) texts written in time too short from the creation of the base work to include them in the category of "working through" the Holy Scriptures; 5) Jewish texts from the period when the canon of the Bible was already defined and the biblical text obtained the status of canonical and unchangeable. Other categories, such as legal texts, should be added. These are minimal but necessary restrictions to make the RewB category functional and clear.

Moshe Bernstein and Michael Segal argued in favour of adhering to a more stark understanding of the concept, excluding, for example, the Palestinian Targumic literature. Bernstein formulates a valid postulate: "In my view, in order to achieve greater methodological precision in our work on the ways in which the Bible is transmitted, translated, retold and interpreted in early Judaism, our classifications must be as sharply drawn as we can make them. Only after marking that which distinguishes literary forms from one another can we proceed to compare those features in divergent genres which appear to draw them together." ${ }^{45}$ According to Bernstein, and I agree with him here, if we want to expand the research field delineated by Géza Vermes, it is only by adding legal texts.

In using the RewB category today, the point is not only to indicate examples (which is what it usually ends up at), but also to give its precise definition and delimitation of the level of analysis to which it may be applied. Criteria that either include or exclude works from this collection must be indicated, so that the discussion between researchers is possible and does not constantly revolve around definition

45 Bernstein, "Rewritten Bible," 175. See also Segal, "Between Bible," 10-29. 
problems. ${ }^{46}$ An overly broadly defined category is no longer productive, as it covers most of the Jewish literature of the Second Temple period. In such a broad sense, almost every work becomes para-biblical by the fact that it alludes to biblical stories or law. Although the RewS should not be seen in the modern category of genre, as I will try to show below, it can be understand as a literary activity defined by certain external and internal characteristics. "Rewriting" is a specific form of working with the base text, a limited intervention in the text, an explanation or addition following the scriptural narrative, that is, a different type of work than translation into another language or, on the other hand, a text loosely referring to biblical motives. We consider here compositions that are clearly based on the Scriptures, those that run parallel to the text of one or more biblical books at the time, when the canon of the Bible was not yet established. The text of the Bible remains the organizing principle of the retold Bible.

\section{Literary Genre or Interpretative Process?}

Géza Vermes was changing his approach to what he described as the RewB. Initially, he seemed to treat it as an exegetical technique or textual strategy, later he wrote about it as a literary genre. Many researchers have asked whether the RewB is a specific literary genre, a writing technique characteristic of a few related genres, or a working method that could be used in any genre and any literary form? Should it be used as a modern technical term for a specific genre, limiting its use to literature that meets clearly defined criteria? Or maybe it defines a certain current of inter-testamental literature and covers the spectrum of works and genres with multiple relation to the texts of the sacred Scriptures?

Researchers are divided between seeing rewritten Scripture as a genre and a working method. ${ }^{47}$ The problem of Géza Vermes and subsequent researchers with specifying the literary specificity of this phenomenon is symptomatic, because it seems that ancient authors themselves perceived their activity very differently. The author of the Book of Jubilees was convinced of the inspired nature of his work, while for Josephus quite the opposite was true. Rewritten Scripture authors did not seem to assume a ready-made and well-defined literary pattern. On the other hand, the method of work and the literary effect are similar: it is always a reworking of the biblical tradition in accordance with the current needs of the religious or secular community.

\footnotetext{
46 The first to compile such a list of the characteristics of RewB was Alexander ("Retelling the Old Testament," 116-118). This list can still be used as a starting-point for discussion.

47 See Harrington, "The Bible Rewritten," 239-247; Brooke, "Rewritten Bible," 777-781.
} 
It seems that the authors perceived their activity in terms of a broadly understood reinterpretation and update of the sacred traditions of Judaism.

Philip Alexander argued for an understanding of the concept in terms of a genre. He provided nine extensive characteristics and claimed that any text to be included in this particular genre should possess all nine characteristics. ${ }^{48}$ However, scholars like George Nickelsburg and Harrington understood the concept as a textual strategy, what allowed them to classify other texts under the rubric. With a increasing number of texts being included the way was paved for the subsequent development of the category.

Two arguments seem crucial here: the diversity of the texts in which we notice a characteristic rewriting process, and the generic diversity within the text itself. First, the diversity of works normally included in the notion, variations in form, subject matter, style, and theological emphases in Jubilees, Genesis Apocryphon, the Temple Scroll, 4QReworked Pentateuch, Pseudo-Philo, and Josephus' Antiquities preclude viewing them as generically unified. The inclusion to RewS of the works such as the Jubilees, Genesis Apocryphon or Ant. 1-11 does not preclude simultaneous participation of these texts in genres, such as narrative, law or apocalypse a bit like satire, which can appear in any other literary genre. The rewritten Scripture phenomenon seems to be not so much a genre but a kind of umbrella category that covers the spectrum of ancient Jewish works from Second Temple period and various ways of remodeling biblical material. As Jewish Scripture of the Second Temple period comprised various genres - e.g., legendary narratives, laws, historiography, prophetic visions and oracles, and other types of poetry - a given text classified as RewS could belong to any one of these. ${ }^{49}$

Second, there is one feature of the texts in this category that captures the nature of RewB. Within one work, we can find passages that are simply biblical texts and those that are retold biblical texts. Good examples are Chronicles and 4QRP, where large parts of the texts are identical to the originals, while others are slightly or strongly changed. Moshe Bernstein admits to his consternation about the $4 \mathrm{QRP}$, seeing it once as a biblical text and once as a RewB, analogous to the Book of Jubilees. ${ }^{50}$ Steven Fraade recently showed that the Temple Scroll incorporate a mixture of textual forms and classes, including that of RewB or "Reworked Pentateuch," but also others. ${ }^{51}$ Texts like Jubilees and the Temple Scroll are of mixed styles and methods (e.g., rewritten Bible, reworked Pentateuch, narratives, and topically grouped laws), which should not be smoothed over in the desire to fit each within in a single genus

\footnotetext{
48 Alexander, "Retelling the Old Testament," 118f.

49 Zahn, "Genre and Rewritten Scripture," 274.

50 Bernstein, "Rewritten Bible," 183: "I am still uncertain myself, however, of the genre of 4QRP as a whole, and feel virtually trapped between the Scylla of calling it a biblical text and the Charybdis of referring to it as a biblical commentary form of 'Rewritten Bible."

51 Fraade, "The Temple Scroll," 144.
} 
or genre. We also have to take into account the compositions, only a part of which can be classified as RewS. In contrast to Jubilees or Antiquities, which can be seen as RewS in their entirety, among copies of $4 \mathrm{QRP}^{\mathrm{a}-\mathrm{e}}$ only $4 \mathrm{QRP}^{\mathrm{a}}$ reflects the rewritten phenomenon identified by Géza Vermes (4QRP ${ }^{\mathrm{b}-\mathrm{e}}$ merely exhibit minor revisions). Moreover, several of texts from the category have a characteristic that links them with both other texts of RewS and texts that would not be normally admitted to that group - e.g. pseudepigrapha and apocrypha with thematically related fragments. Therefore, the RewB phenomenon cannot be closed and limited to one work or another and its specific genre. It permeates various works and various literary genres. Rewriting Scripture is rather a type of literary activity, a specific writing tendency, assuming the biblical text as the starting point for its work. The variety of forms of texts in this category and the complexity of this activity prevent it from being narrowly treated as one genus.

Finally, recent studies have made clear that the techniques used to reconfigure the scriptural text in works usually labeled RewS are fundamentally the same as those used to produce revised versions of the scriptural texts themselves; that is, new copies of scriptural books. David Carr in particular has demonstrated the extent to which revision and reconfiguration of earlier works was a standard mode of literary production in the ancient world. ${ }^{52}$

These arguments are convincing. Scholars increasingly tend to speak about an interpretational activity of "rewriting Scripture" rather than of a formal genre..$^{53}$ Géza Vermes responded to this by trying to combine both approaches; he wrote: „The question has been raised whether the "Rewritten Bible" corresponds to a process or a genre? In my view, it verifies both. The person who combined the biblical text with its interpretation was engaged in a process, but when his activity was completed, it resulted in a literary genre." ${ }^{54}$ Does such an approach touch the essence of the phenomenon and its complexity? The recognition that we are dealing with a more comprehensive phenomenon of intertextuality appearing in various genre texts seems more promising. The texts related to the Bible found at Qumran show a variety of exegetical techniques and hermeneutic strategies used to rewrite their

52 See more in Zahn, "Genre and Rewritten Scripture," 274f. She asks: "If the rewriting that is constitutive of the category Rewritten Scripture is something that simply took place in the course of the scribal transmission of sacred texts - or, indeed, of any texts - how can Rewritten Scripture be identified as a separate genre primarily on the basis of that rewriting?" (ibidem). The author, however, points out that in a broader, more flexible and theoretical sense one can speak here of a genre: "Their rewriting of prior Scripture perhaps in conjunction with other shared characteristics - could constitute sufficient reason to consider Jubilees and the Temple Scroll and others as also participating in a distinct genre called Rewritten Scripture" (ibidem). This position is not entirely convincing and, in my opinion, contains some elements of an anachronistic approach (assuming contemporary categories of thought). More on the genre theory and genres in historical perspective see in her new book: Genres of Rewriting in Second Temple Judaism.

53 Falk, The Parabiblical Texts, 4-14; Petersen, "Rewritten Bible," 292-297; Petersen, "The Riverrun of Rewriting Scripture," 475-496; Teeter, "On 'Exegetical Function," 373-402.

54 Vermes, "The Genesis of the Concept," 8. 
literary antecedents. These techniques appear to be very similar to the exegetical strategies that can be traced back even to the earliest stages of the development of the Hebrew Bible itself, where similar phenomena are found. It would be very difficult to reduce this phenomenon to a specific literary genre. The six examples of literature (including the Targums and Sepher ha-Yashar) to which Géza Vermes originally assigned the classification are already too diverse in terms of genre to be attributed the same generic rubric..$^{55}$ RewS is best understood as a re-writing strategy, the writer's interpretative involvement, a special form of intertextuality that implies a close relationship between the original authoritative text and its reworking.

I think we can again speak of an anachronistic approach in this case. George Brooke appears to be right that in Second Temple Period there was no such thing as a "Rewritten Scripture" literary genre with clearly defined genre traits. ${ }^{56}$ Rather, it was a certain method of work, the fruit of which is a spectrum of writings with variegated relevance to the text of the Bible each time. It is reasonable to ask whether, by classifying a work as RewB genre, we are not limiting our ability to recognize other aspects of its specific structure and rhetoric that would align it with aspects of other similar texts of the late Second Temple period. The Temple Scroll alerts us that such anachronistic approach, like a searching of specific literary genre chosen by the author may not be effective. Rather, what the author chooses for all or part of his work is a certain modus operandi.

\section{What Are the Purposes of Rewriting the Scriptures?}

In addition to the characteristic manner of the Vorlage-dependent composition, rewritten Scripture also has a specific function or functions. Since its appearance in research, many scholars have understood this phenomenon in the context of Jewish interpretation of the Holy Scriptures. Géza Vermes considered RewB to be incorporation of interpretation directly into the biblical narrative. For Philip Alexander, Moshe Bernstein and James Kugel, the main reason why rewritten Scripture should be viewed as a means of interpreting the Scriptures is that it contains many of the exegetical motives known from later biblical commentaries. ${ }^{57}$ These researchers point out that the phenomenon of re-telling the Bible is essentially the same or similar kind of endeavor as commentary, both of which seek to answer the questions posed in the texts and relate them to issues relevant to current readers.

55 Petersen, "Textual Fidelity," 29. Similarly, Jonathan Campbell, see Campbell, "Rewritten Bible: A Terminological Reassessment," 55-58.

56 Brooke, "Genre Theory," 361-386.

57 Alexander, "Retelling the Old Testament," 101; Bernstein, "Rewritten Bible," 180; Kugel, In Potiphar's House, passim. 
So is rewritten Scripture a form of biblical commentary? It seems that one cannot agree with this approach to the matter. The re-narrated Bible, though looks like a specific form of commentary, seems to be a different kind of creative activity. Author often omits entire fragments of the narrative known from the biblical books and modifies others. Thus, he deeply interferes with the source text and changes it irreversibly. Such activity cannot be reduced to the role of a commentary. The reader of the RewB may not have had any contact with the source text. Thus, rewritten Scripture ceases to be a commentary, and becomes the source text that was to be commented on. A commentary is a work which is by nature not self-dependent. It belongs to and makes sense only in conjunction with the interpreted original. Works of rewritten Scripture are often completely detached from their Vorlagen and function as autonomous, individual works. Reducing the phenomena of rewritten Scripture to the role of commentary also underestimates the variety of literary genres in which the Jewish biblical interpretation of late antiquity expresses itself.

According to Campbell, ancient readers would not have considered a work such as the Book of Jubilees as "rewriting" the books of Genesis and Exodus. His research position rejects the interpretation of Jubilees as having an intended interpretative or exegetical function..$^{58}$ Although Campbell goes too far, emphasizing the independence of these works to the point of negating the phenomenon of rewriting as such, he raises the question whether the interpretation of Scripture in such works is a deliberate and targeted exegetical activity or it is rather incidental and accidental. Is exegesis part of the actual purpose and function of a text such as the Jubilees? Or is the interpretive function a byproduct of the creative use of existing sources in the creation of new texts? It is not easy to answer these questions, just as it is difficult to answer questions about the function of many ancient works at all. There is rarely a clear-cut rationale for setting such a goal with a high level of certainty.

Perhaps the best example here will be the Book of Jubilees. On the one hand, one can immediately notice significant chronological, apocalyptic and legal additions that do not have the function of a commentary, because they add completely new traditions to the content of the Book of Genesis. On the other hand, the author's interpretative and exegetical activity is clearly visible. In many places, Jubilees supplements the biblical narrative with a number of secondary details that do not appear to be of great ideological significance. For example, the names of many wives and daughters have been added, and genealogies have been supplemented. Where the Book of Genesis is inconsistent, repeating or omitting important details (which was a pretext for diachronic studies of the Pentateuch and the search of its "sources"), the Book of Jubilees creates a narrative that is smooth, chronologically consistent and devoid of contradictions or controversies. One example is the transposition of Gen 37:1-2, Jacob's settling and the age of Joseph, from its position before Joseph's 
sale (Jub. 34:10) to Jub. 39:2, Joseph in the house of Potiphar. This verse is transposed precisely for the purposes of creating a smoother narrative. This transposition is due to narrative resumption. It follows the long extra portion of the war between Jacob and Esau, and re-centers the narrative on Joseph. ${ }^{59}$

One of the important purposes of the rewritten Scripture was to solve the difficulties that are present in the biblical text. ${ }^{60}$ For example, in Gen 4:17 it is mentioned that Cain had relations with his wife, and she conceived and bore Enoch. ${ }^{61}$ To this moment, nowhere in Genesis 1-4 is there mention of Cain's wife, moreover, of no other woman than Eve. So where did Cain get a wife from? Only in Genesis 5 - a text from a different tradition, different "source" - it is said that Adam had other sons and daughters (Gen 5:4), but it is still unknown when they were born and whether Cain married one of them. The Book of Jubilees addresses this difficulty by telling in one continuous section the birth of two sons, Cain and Abel, but also a daughter, Awan (Jub. 4:1). Earlier in the creation narrative, there is a detailed account of the creating of angels on the first day (Jub. 2:2). In this way, the author of Jubilees fills a large gap in the genesis of beings so important in the theology of the Second Temple. The reader of midrashic literature is familiar with this practice of supplementing and "fixing" the biblical text because it is commonly used in targums and midrashes ${ }^{62}$ The additional material is sometimes used to resolve visible contradictions in the Bible and sometimes to fill gaps in the story, such as the names of minor characters or the inner motivation of the hero's actions. This form of rewriting also involves updating what some scholars call "applied exegesis," that is, such a presentation of the meaning of the text that will be relevant to the reader or that authenticates beliefs and practices close to the author.

Certainly one of the motivating factors behind scribal intervention in the tradition was a felt desire for clarification of the meaning or sense of the base text. But much more seems to be at play than simple sense exegesis. Let's see another example, the Temple Scroll. Some scholars tended towards understanding it as primarily an exegetical text, and sought to offer exegetical motivations or biblical precedent even for those sections of the Scroll that have no parallel in earlier pentateuchal traditions. ${ }^{63}$ But as Fraade has recently shown, major aspect of the Temple Scroll is the grouping of laws according to topical rubrics (and not according to the progression of a narrative plot), something for which we have seen several analogues in late Second Temple

59 Jubilees remove details irrelevant to Israelite history, omit redundancies and erase verses that lead to contradiction or discomfort. The author/redactor tries to tighten narrative flow, connect one story to another, and even provide an entirely new meaning to an older biblical narrative. See more in Berkovitz, "Missing and Misplaced?", 40-63.

60 Fröhlich, "Narrative Exegesis," 82.

61 Translation after the New American Bible (NAB).

62 See, for example, Kaczorowski, Wprowadzenie do Midrasza Bereszit Rabba.

63 Callaway, "Extending Divine Revelation," 149-162; Swanson, The Temple Scroll. 
literature (as in the later Mishnah), some of which fit within the rubric of RewS, whereas others of which clearly do not. ${ }^{64}$ For Fraade, "the rewriting of a legal text respond to different intellectual needs and accomplish different rhetorical goals." ${ }^{\prime \prime}$ Molly Zahn in the same 2018 volume explored the issue of "exegesis" versus "ideology" in a fragment of the Temple Scroll. ${ }^{66}$ She shows that "exegesis cannot really be separated from ideology" and that "the interpretive solution offered in Temple Scroll is highly ideological in nature." 67

Telling the Scripture anew is a form of interpreting inherited sacred texts of one's own religion, but not in the way of commenting on them, but rather - at least in some cases - replacing them with a completely new work (the Books of Chronicles and the Temple Scroll were probably created for this purpose) ${ }^{68}$ How faithfully the text of the Vorlage has been preserved or how much it has been changed depends on the shared and not shared ideological and theological paradigms of the authors. ${ }^{69}$ Deliberate omissions appear in the process of transmitting the Hebrew text of the Bible and have ideological or theologically motivated goals. Fragments are not only omitted, but also consciously changed by later editors, if they found them embarrassing, controversial or contrary to their later understanding. ${ }^{70}$ The Books of Chronicles are an excellent example of changes in the transmission of the text that are related to changes in theological and ideological paradigms. They show here a great resemblance to the Book of Jubilees and the Temple Scroll.

Thus, rewritten Scripture, as is to be expected, follows the biblical narrative, except when it edits the text to represent the author's point of view. Here lies one of the keys to understanding the phenomenon of rewriting. The idea that the author was trying to convey is in the changes made to the text - whether they are omissions, additions, or modifications to the content itself. If the author integrates changes and revisions into the narrative according to his theological goals, it is these revisions that create a window into the world of his own ideas and purposes.

The RewB contains much more than a repetition of a biblical narrative or biblical law, just as the Book of Deuteronomy is not only a re-account of tradition from

64 Fraade, "The Temple Scroll," 154.

65 Fraade, "The Temple Scroll," 153.

66 Zahn, "Exegesis, Ideology," 330-342.

67 Zahn, "Exegesis, Ideology," 331.

68 Wacholder, "The Relationship," 205-216. For a discussion of whether the RewS texts attempt to replace their scriptural antecedents or not, see in Petersen, "Textual Fidelity," 13-48 (esp. 31-35). He makes an important observation: "Texts exhibiting rewritten Scripture may be understood as an attempt to make authoritative texts of the past present in new contexts; yet, at the same time, they may also by virtue of being rewritings justifiably be viewed as engaged in the attempt to functionally replace their scriptural antecedents" (ibidem, 14). Molly Zahn ("Rewritten Scripture," 331)proposes a similar conclusion: "it does seem appropriate to say that rewritten texts, especially those with strong authority claims, in certain ways do seek to replace the texts that they rewrite." See also Glas, Between Transmission and Revision.

69 Pakkala, God's Word Omitted, 117.

70 Pakkala, God's Word Omitted, 212-213. 
Exodus-Numbers, but a new map of thoughts, ideas and theological truths. Endres notes: "The effort expended on this re-writing of the sacred story suggests that the author intended to proclaim or to teach important doctrines or behaviors by means of this re-writing." ${ }^{\text {"71 }}$ It seems that the important goal of the rewritten Scripture is more extensive than commenting, supplementing, or exegetically explaining the details of a biblical text - as is often claimed. It rather consists in presenting the narrative of the Holy Scripture a way that will convey the most important ideas and beliefs of the author to the next generations of recipients of sacred traditions. The point is to create a new medium for new values.

\section{Conclusion}

Most of the works found at Qumran and around the Dead Sea have to do with the books that later became known as the Hebrew Bible. One group of these manuscripts was referred to, after Géza Vermes, as the RewB. These are texts that "rewrite" biblical narratives, but with a characteristic rearrangement: omissions, additions and modifications to traditions known from Scripture.

Existing examples of this important phenomenon illustrate the central place which the writings that later attained the status of the Holy Scripture had for Jews during the Second Temple period. A special role here is played by the Pentateuch, the Hebrew Torah, which has the greatest number of pseudo-epigraphic texts, apocrypha, midrashes and commentaries based on it. Among the works of RewS, texts based on the authority of the Pentateuch also dominate. However, this authority was understood differently than today. The authors of the works of RewS saw no problem in modifying, deleting or even changing the theological meaning of the traditions contained in the Torah, so as to achieve an effect significant for their own groups of recipients.

In antiquity, the text was not published, as it is done today, but it was rewritten by making copies and enriching them with comments placed directly in the text. These rearrangements resulted from constant reflection on the text and new experiences. The phenomenon of remodeling old religious traditions goes beyond Judaism and the Bible, it is well known in the Ancient East. By this I mean, for example, various versions and re-workings of the epic of Gilgamesh. The study of these types of texts excludes the possibility of simple juxtaposition of existing sources next to each other, and yet this assumption was the basis of the classic Documentary Hypothesis of Julius Wellhausen. Also, we are not dealing with adding together ready-made units, as suggested, for example, in the case of the Jacob cycle and the Joseph cycle in the Book

71 Endres, Biblical Interpretation, 15. 
of Genesis. Rather, we observe the far-reaching, free interference of the authors with the original sources: their modeling, including cutting out unwanted fragments and adding appropriate ones. The same editorial strategies were used in Mesopotamia and Israel. The analysis of the rewritten Scripture phenomenon sheds a lot of valuable light on the process of composing ancient literature, including biblical literature, which has been one of the dominant topics since the beginning of modern biblical studies.

\section{Bibliography}

Alexander, P.S., "Retelling the Old Testament," It Is Written. Scripture Citing Scripture. Essays in Honour of Barnabas Lindars (eds. D.A. Carson - H.G.M. Williamson) (Cambridge: Cambridge University Press 1988) 99-121.

Berkovitz, A.J., "Missing and Misplaced? Omission and Transposition in the Book of Jubilees," Hā- 'îsh Mōshe. Studies in Scriptural Interpretation in the Dead Sea Scrolls and Related Literature in Honor of Moshe J. Bernstein (eds. B.Y. Goldstein - M. Segal - G.J. Brooke) (Leiden: Brill 2018) 40-63.

Bernstein, M.J., “«Rewritten Bible»: A Generic Category Which Has Outlived its Usefulness?, Textus 22 (2005) 169-196.

Brooke, G.J., "Rewritten Bible," Encyclopedia of the Dead Sea Scrolls (eds. L.H. Schiffman J.C. VanderKam) (New York: Oxford University Press 2000) II, 777-781.

Brooke, G.J., "Genre Theory, Rewritten Bible and Pesher," Dead Sea Discoveries 17 (2010) 361-386.

Callaway, P.R., "Extending Divine Revelation: Micro-Compositional Strategies in the Temple Scroll," Temple Scroll Studies (ed. G.J. Brooke) (Sheffield: JSOT Press 1989) 149-162.

Campbell, J.G., "«Rewritten Bible» and «Parabiblical Texts»: A Terminological and Ideological Critique," New Directions in Qumran Studies. Proceedings of the Bristol Colloquium on the Dead Sea Scrolls, 8-10th September 2003 (eds. J.G. Campbell et al.) (London: Clark 2005) 43-68.

Campbell, J.G., "Rewritten Bible: A Terminological Reassessment," Rewritten Bible after Fifty Years. Texts, Terms, or Techniques? (ed. J. Zsengellér) (Supplements to the Journal for the Study of Judaism 166; Leiden: Brill 2014) 49-82.

Crawford, S.W., Rewritten Scripture in Second Temple Times (Grand Rapids, MI: Eerdmans 2008).

Endres, J.C, Biblical Interpretation in the Book of Jubilees (Washington, D.C.: Catholic Biblical Association of America 1987).

Falk, D.K., The Parabiblical Texts. Strategies for Extending the Scriptures in the Dead Sea Scrolls (London: Clark 2007).

Feldman, A. - Goldman, L., Scripture and Interpretation. Qumran Texts that Rework the Bible (ed. D. Dimant) (Berlin: De Gruyter 2014). 
Flusser, D., "Palaea Historica: An Unknown Source of Biblical Legends," Studies in Aggadah and Folk-Literature (eds. J. Heinemann - D. Noy) (Jerusalem: Hebrew University Magnes Press 1971) 48-79.

Fraade, S.D., "The Temple Scroll as Rewritten Bible: When Genres Bend," Hā-' 'ish Mōshe. Studies in Scriptural Interpretation in the Dead Sea Scrolls and Related Literature in Honor of Moshe J. Bernstein (eds. B.Y. Goldstein - M. Segal - G.J. Brooke) (Leiden: Brill 2018) 136-154.

Friis, M., Translations, adaptations and transformations of Scripture in Fl. Josephus' "Antiquities of the Jews," https://www.academia.edu/4402800/Translations_adaptations_and_transformations_of_Scripture_in_Flavius_Josephus_Antiquities_of_the_Jews [access: 29.06.2021].

Fröhlich, I., "«Narrative Exegesis» in the Dead Sea Scrolls," Biblical Perspectives. Early Use and Interpretation of the Bible in Light of the Dead Sea Scrolls (Studies on the Texts of the Desert of Judah 28; Leiden: Brill 1998).

Glas, J.E., Between Transmission and Revision. Exegesis and Intertextuality in $4 \mathrm{QRPa} 1-2$, https:// www.academia.edu/16071110/MA_paper_Between_Transmission_and_Revision_ Exegesis_and_Intertextuality_in_4QRewritten_Pentateuch_a_1_2 [access: 01.07.2021]. Halpern-Amaru, B., Rewriting the Bible. Land and Covenant in Postbiblical Jewish Literature (Valley Forge, PA: Trinity Press International 1994).

Harrington, D.J., “The Bible Rewritten (Narratives)," Early Judaism and Its Modern Interpreters (eds. R.A. Kraft - G.W.E. Nickelsburg) (Atlanta, GA: Scholars Press 1986) 239-247.

Jacobson, H., A Commentary on Pseudo-Philo's Liber Antiquitatum Biblicarum, with Latin Text and English Translation (Leiden: Brill 1996).

Kaczorowski, W., Wprowadzenie do Midrasza Bereszit Rabba na podstawie rabinicznej interpretacji historii Abrahama i Sary (Kraków: Księgarnia Akademicka 2021).

Kugel, J.L., In Potiphar's House. The Interpretive Life of Biblical Texts (San Francisco, CA: HarperSanFrancisco 1990).

Lange, A., "The Status of the Biblical Texts in the Qumran Corpus and the Canonical Process," The Bible as Book. The Hebrew Bible and the Judaean Desert Discoveries (eds. E.D. Herbert - E. Tov) (London: British Library 2002) 21-30.

Malan, G.J., "Is Rewritten Bible/Scripture the Solution to the Synoptic Problem?," HTS Teologiese Studies/Theological Studies 70 (2014) 1-10.

Minov, S., "Satan's Refusal to Worship Adam: A Jewish Motif and Its Reception in Syriac Christian Tradition," Tradition, Transmission, and Transformation from Second Temple Literature through Judaism and Christianity in Late Antiquity (eds. M. Kister et al.) (Leiden: Brill 2015) 230-271.

Müller, M. - Tang Nielsen, J. (eds.), Luke's Literary Creativity (London - New York: Bloomsbury Clark 2016).

Najman, H., “The Vitality of Scripture within and beyond the Canon," Journal for the Study of Judaism 43 (2012) 497-518.

Pakkala, J., God's Word Omitted. Omissions in the Transmission of the Hebrew Bible (Göttingen: Vandenhoeck \& Ruprecht 2013).

Parchem, M., “Testament Mojżesza. Wprowadzenie oraz przekład z objaśnieniami,” Collectanea Theologica 76/2 (2006) 79-103. 
Petersen, A.K., "Rewritten Bible as a Borderline Phenomenon: Genre, Textual Strategy, or Canonical Anachronism?", Flores Florentino. Dead Sea Scrolls and Other Early Jewish Studies (eds. A. Hilhorst - É. Puech - E.J.C. Tigchelaar) (Leiden: Brill 2007) 285-306.

Petersen, A.K., "The Riverrun of Rewriting Scripture: From Textual Cannibalism to Scriptural Completion," Journal for the Study of Judaism 43 (2012) 475-496.

Petersen, A.K., “Textual Fidelity, Elaboration, Supersession or Encroachment? Typological Reflections on the Phenomenon of Rewritten Scripture," Rewritten Bible after Fifty Years. Texts, Terms, or Techniques? (ed. J. Zsengellér) (Supplements to the Journal for the Study of Judaism 166; Leiden: Brill 2014) 13-48.

Reed, A.Y., "Retelling Biblical Retellings: Epiphanius, the Pseudo-Clementines, and the Reception-History of 'Jubilees,' Tradition, Transmission, and Transformation from Second Temple Literature through Judaism and Christianity in Late Antiquity (eds. M. Kister et al.) (Leiden: Brill 2015) 304-321.

Segal, M., "Between Bible and Rewritten Bible," Biblical Interpretation at Qumran (eds. M. Henze) (Grand Rapids, MI: Eerdmans 2005) 10-29.

Swanson, D.D., The Temple Scroll and the Bible. The Methodology of 11QT (Leiden: Brill 1994). Talshir, Z., "The Relationship between Sam-MT, 4QSama, and Chr and the Case of 2 Sam 24," In the Footsteps of Sherlock Holmes. Studies in the Biblical Text in Honour of Anneli Aejmelaeus (eds. K. De Troyer et al.) (Leuven: Peeters 2014) 273-298.

Teeter, D.A., “On 'Exegetical Function' in Rewritten Scripture: Inner-Biblical Exegesis and the Abram/Ravens Narrative in Jubilees," Harvard Theological Review 106 (2013) 373-402.

Tov, E., "3 Kingdoms Compared with Similar Rewritten Compositions," Flores Florentino. Dead Sea Scrolls and Other Early Jewish Studies (eds. A. Hilhorst - É. Puech - E.J.C. Tigchelaar) (Leiden: Brill 2007) 345-366.

Tov, E., "The Many Forms of Hebrew Scripture: Reflections in Light of the LXX and 4QReworked Pentateuch," From Qumran to Aleppo. A Discussion with Emanuel Tov about the Textual History of Jewish Scriptures in Honor of His 65th Birthday) (eds. A. Lange M. Weigold - J. Zsengellér) (Gottingen: Vandenhoeck \& Ruprecht 2009) 11-28.

Van Loon, G.J.M., " "The Meeting of Abraham and Melchizedek» and the «Communion of the Apostles»," Coptic Studies on the Threshold of a New Millennium (eds. M. Immerzeel J. van der Vliet) (Leuven: Peeters 2004) 1381-1400.

VanderKam, J.C., "The Wording of Biblical Citations in some Rewritten Scriptural Works," The Bible as Book. The Hebrew Bible and the Judaean Desert Discoveries (eds. E.D. Herbert - E. Tov) (London: British Library 2002) 41-56.

VanderKam, J.C., "Questions of Canon Viewed through the Dead Sea Scrolls," The Canon Debate (eds. L.M. McDonald - J.A. Sanders) (Peabody: Hendrikson 2002) 91-109.

Vermes, G., "Biblical Midrash," The History of the Jewish People in the Time of Jesus Christ (ed. E. Shürer) (Edinburgh: Clark 1986) III, 308-341.

Vermes, G., "Bible Interpretation at Qumran," Eretz-Israel 20 (1989) 184-191.

Vermes, G., "The Genesis of the Concept of «Rewritten Bible»," Rewritten Bible after Fifty Years. Texts, Terms, or Techniques? (ed. J. Zsengellér) (Supplements to the Journal for the Study of Judaism 166; Leiden: Brill 2014) 3-9.

Vermes, G., Scripture and Tradition in Judaism (Leiden: Brill 1961). 
Wacholder, B.Z., “The Relationship between 11QTorah (The Temple Scroll) and the Book of Jubilees: One Single or Two Independent Compositions," SBL Seminar Papers 24 (1985) 205-216.

Zahn, M.M., "Exegesis, Ideology, and Literary History in the Temple Scroll: The Case of the Temple Plan," Hā- 'îsh Mōshe. Studies in Scriptural Interpretation in the Dead Sea Scrolls and Related Literature in Honor of Moshe J. Bernstein (eds. B.Y. Goldstein - M. Segal - G.J. Brooke) (Leiden: Brill 2018) 330-342.

Zahn, M.M., "Genre and Rewritten Scripture: A Reassessment," Journal of Biblical Literature 131 (2012) 271-288.

Zahn, M.M., "Rewritten Scripture," The Oxford Handbook of the Dead Sea Scrolls (eds. T.H. Lim J.J. Collins) (Oxford: Oxford University Press 2010) 323-336.

Zahn, M.M., "The Problem of Characterizing the 4QReworked Pentateuch Manuscripts: Bible, Rewritten Bible, or None of the Above," Dead Sea Discoveries 15 (2008) 315-339.

Zahn, M.M., "Torah for 'The Age of Wickedness': The Authority of the Damascus and Serekh Texts in Light of Biblical and Rewritten Traditions," Dead Sea Discoveries 20 (2013) 410-432.

Zahn, M.M., Genres of Rewriting in Second Temple Judaism. Scribal Composition and Transmission (Cambridge: Cambridge University Press 2020).

Zahn, M.M., Rethinking Rewritten Scripture. Composition and Exegesis in the 4QReworked Pentateuch Manuscripts (Leiden: Brill 2011).

Zsengellér, J. (ed.), Rewritten Bible after Fifty Years. Texts, Terms, or Techniques? (Supplements to the Journal for the Study of Judaism 166; Leiden: Brill 2014). 